\section{BY DECLAN BUTLER}

$\mathrm{I}$ f you thought that the controversy was over, think again. Last week's publication of the second of two papers describing how to make mammalian-transmissible forms of the $\mathrm{H} 5 \mathrm{~N} 1$ avian influenza virus merely closes one chapter of a smouldering debate about the risks of the research. That debate seems certain to reignite in the coming months once researchers lift a voluntary moratorium on the work.

The research published last week, led by Ron Fouchier at the Erasmus Medical Centre in Rotterdam, the Netherlands, showed that introducing as few as five genetic mutations made the $\mathrm{H} 5 \mathrm{~N} 1$ virus capable of airborne spread between ferrets ${ }^{1,2}$. It followed similar work published in $\mathrm{May}^{3}$ by Yoshihiro Kawaoka's groups at the University of Wisconsin-Madison and the University of Tokyo.

In December 2011, the US National Science Advisory Board for Biosecurity (NSABB) had recommended that only redacted portions of the papers should be published, mainly on the grounds that divulging the detailed methods could increase the risk of bioterrorism. But, after much wrangling, the NSABB in March finally agreed to the publication of updated versions of the full papers ${ }^{4}$.

Supporters of the research say that it could help public-health experts to detect ominous genetic changes in nature, providing an early warning of an emerging flu pandemic. Others are sceptical, and point out that an expansion of research to pursue this goal would probably see similar mutant viruses being created in dozens more labs worldwide - some of which may lack adequate biosafety standards. That would multiply the risk of an accidental release of a pathogen capable of sparking a pandemic.

For now, the research moratorium agreed by 39 leading flu scientists in January and extended at a meeting convened by the World Health Organization (WHO) in Geneva in February ${ }^{5}$ is allowing the field to discuss how to proceed safely. The moratorium would only be lifted, experts at the meeting agreed, once funders and regulators had worked out the biosafety and biosecurity conditions that would allow such research to be conducted with reasonable guarantees of safety. The meeting also resulted in a public-relations campaign to influence public opinion about the research and its potential benefits.

Flu researchers will soon be able to argue that those conditions have been met. "We have heard from several researchers that they would like to lift the moratorium sooner rather than

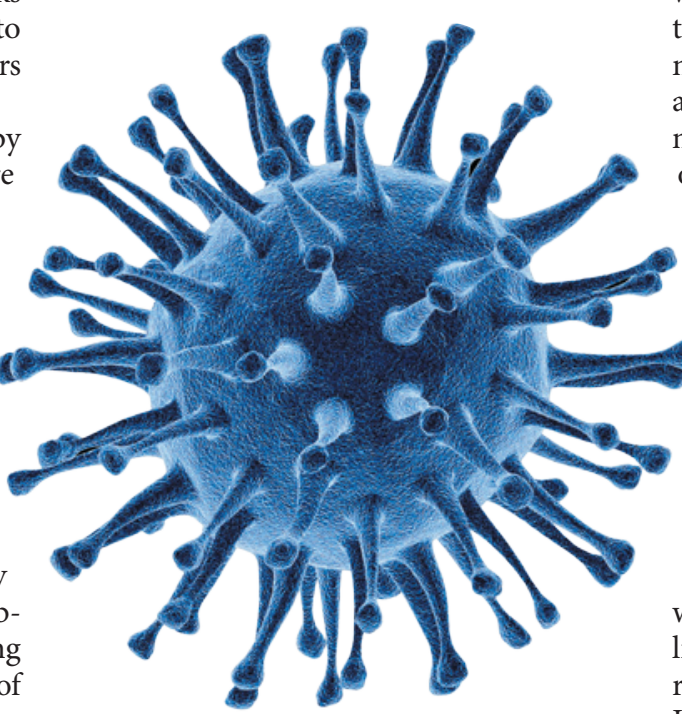

Just a few genetic tweaks can enable the H5N1 avian flu virus to transmit between mammals.

later," says Fouchier, one of its signatories.

In a few weeks, the WHO will unveil nonbinding biosafety and biosecurity guidelines for mutant-flu research. Over the following months, national regulatory authorities are expected to produce their own biosafety rules. In the United States, which is the main funder of this type of flu research, a joint committee of federal agencies - the Intragovernmental Select Agents and Toxins Technical Advisory Committee - is expected to issue its own biosafety rules soon. A more detailed plan the United States Government Policy for Local Institutional Oversight of Dual Use Research of Concern - is also likely to be released for public comment soon, possibly within weeks, says Anthony Fauci, director of the US National Institute of Allergy and Infectious Diseases (NIAID) in Bethesda, Maryland.
But Fauci says that he is keen to restart the research before the final policy is published months from now. He intends to hold a discussion on future plans for this work at the annual meeting of the NIAID Centers of Excellence for Influenza Research and Surveillance in New York at the end of July, which will be attended by many of the moratorium's signatories. "I can't say that the moratorium will officially end then, but we are certainly going to address the topic at that meeting," he says, "to get some research going on an interim basis."

The moratorium only involves the handful of groups, mostly funded by the US National Institutes of Health, that currently work on 'gain-of-function' experiments that increase the transmissibility or pathogenicity of flu viruses, emphasizes Fauci. "Many people think that the entire field of influenza research is on hold because of this moratorium, and that's not the case."

Some scientists, however, question whether funders should be driving the proliferation of this research. Ilaria Capua, a flu researcher at the Veterinary Public Health Institute in Legnaro, Italy, and a signatory to the moratorium, says that there remains a "central strategic question of whether these experiments should continue at all".

\section{PROLIFERATION CONCERNS}

Advocates of expanding the research say that finding genetic mutations that might make viruses more likely to trigger a pandemic could improve surveillance efforts. But this would require extensive experiments in ferrets and other animals, because the work would involve testing multiple mutations of the many types of wild $\mathrm{H} 5 \mathrm{~N} 1$ virus and the diverse range of other flu viruses with pandemic potential, such as $\mathrm{H} 9$ and $\mathrm{H} 7$ viruses.

"What is going to happen if we decide to continue funding research on this topic, and in 20 years' time we have 200 labs which have such viruses?" asks Capua. With advances in technology bringing mutant-flu research within the reach of many modest labs, even in the world's poorest countries, she worries about its unchecked proliferation in politically volatile regions. "Do we need to continue working on making these viruses 
more and more dangerous, and more and more transmissible? Do the research benefits outweigh the risks?"

The WHO's imminent biosafety guidelines will try to address such proliferation concerns, says one WHO official. Beyond making recommendations about biological containment levels and other physical precautions, the WHO will also suggest that labs should meet the highest standards of safety, attaining international standards for staff training and managing biological risks. The idea, says the WHO official, is to set a high bar for entry into this type of work.

Four leading public-health scientists also called for caution in an article ${ }^{6}$ published in the same issue of Science as Fouchier's paper. Any predictions of flu's behaviour based on its complex genetics and host interactions are "highly speculative", they write, which raises questions about the potential benefit of mutant-virus work to flu surveillance. Moreover, current systems of genetic surveillance of flu viruses are too patchy, and years can pass before samples are sequenced ${ }^{7}$. Contrasting the uncertain benefits with an "exceptional level of risk should motivate exceptional caution by scientists, funders, and regulators worldwide", the authors write ${ }^{6}$.

But Fouchier says that the mutant flu viruses that he and Kawaoka have worked on raise few new biosafety issues. "For over a century, the infectious-disease community has published work on dangerous pathogens while relying on national governments, institutional biosafety offices and the responsibility of scientists to ensure that the work is done under appropriate conditions," Fouchier adds. "Very little has gone wrong so far, so why would that be different now?"

The debate over risks and benefits is likely to come to a head at a meeting that the WHO will convene early next year to discuss the wider implications of high-risk biological research and how researchers, institutions and governments might best assess and manage risk. "The meeting will not be restricted to flu researchers, or virologists or researchers of any sort," says the WHO official. "They will certainly be represented, but so too will other groups which have very legitimate interests and perspectives on this whole question." -

\footnotetext{
1. Herfst, S. et al. Science 336, 1534-1541 (2012).

2. Yong, E. Nature http://dx.doi.org/10.1038/ nature.2012.10875 (2012).

3. Imai, M. et al. Nature http://dx.doi.org/10.1038/ nature10831 (2012).

4. Butler, D. \& Ledford, H. Nature http://dx.doi. org/10.1038/nature.2012.10369 (2012).

5. Butler, D. Nature 482, 447-448 (2012).

6. Lipsitch, M., Plotkin, J. B., Simonsen, L. \& Bloom, B. Science 336, 1529-1531 (2012).

7. Butler, D. Nature 483, 520-522 (2012).
}

\title{
Sea versus senators
}

\author{
North Carolina sea-level rise accelerates while state \\ legislators put the brakes on research.
}

\section{BY LEIGH PHILLIPS}

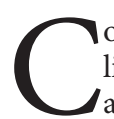
ould nature be mocking North Carolina's law-makers? Less than two weeks after the state's senate passed a bill banning state agencies from reporting that sealevel rise is accelerating, research has shown that the coast between North Carolina and Massachusetts is experiencing the fastest sealevel rise in the world.

Asbury Sallenger, an oceanographer at the US Geological Survey in St Petersburg, Florida, and his colleagues analysed tide-gauge records from around North America. On 24 June, they reported in Nature Climate Change that since 1980, sea-level rise between Cape Hatteras, North Carolina, and Boston, Massachusetts, has accelerated to between 2 and 3.7 millimetres per year. That is three to four times the global average, and it means the coast could see 20-29 centimetres of sea-level rise on top of the metre predicted for the world as a whole by 2100 (A. H. Sallenger Jr et al. Nature Clim. Change http://doi.org/ hz4; 2012).

"Many people mistakenly think that the rate of sea-level rise is the same everywhere as glaciers and ice caps melt," says Marcia McNutt, director of the US Geological Survey.

But variations in currents and land movements can cause large regional differences. The hotspot is consistent with the slowing measured in Atlantic Ocean circulation, which may be tied to changes in water temperature, salinity and density.

North Carolina's senators, however, have tried to stop state-funded researchers from releasing similar reports. The law approved by the senate on 12 June banned scientists in state agencies from using exponential extrapolation to predict sea-level rise, requiring instead that they stick to linear projections based on historical data.

Following international opprobrium, the state's House of Representatives rejected the bill on 19 June. However, a compromise between the house and the senate forbids state agencies from basing any laws or plans on exponential extrapolations for the next three to four years, while the state conducts a new sea-level study.

According to local media, the bill was the handiwork of industry lobbyists and coastal municipalities who feared that investors and property developers would be scared off by predictions of high sea-level rises. The lobbyists invoked a paper published in the Journal of Coastal Research last year by James Houston, retired director of the US Army Corps of Engineers' research centre in Vicksburg, Mississippi, and Robert Dean, emeritus professor of coastal engineering at the University of Florida in Gainesville. They reported that global sea-level rise has slowed since 1930 (J. R. Houston and R. G. Dean J. Coastal Res. 27, 409-417; 2011) - a contention that climate sceptics around the world have seized on.

Speaking to Nature, Dean accused the oceanographic community of ideological bias. "In the United States, there is an overemphasis on unrealistically high sea-level rise," he says. "The reason is budgets. I am retired, so I have the freedom to report what I find without any bias or need to chase funding." But Sallenger says that Houston and Dean's choice of data sets masks acceleration in the sea-level-rise hotspot.

North Carolina is not the only hotspot for efforts to legislate away the reality of sealevel rise. In 2011, the Texas Commission on Environmental Quality removed all references to rising sea levels from a scientific study of Galveston Bay on the Gulf of Mexico. And this month, the Virginia General Assembly passed a bill commissioning a study on rising sea levels - but only after references to sea-level rise and climate change had been removed. - 